ARTICLE

Received 2 Jun 2015 | Accepted 27 Nov 2015 | Published 7 Jan 2016

DOI: $10.1038 /$ ncomms10314

OPEN

\title{
Ice-sheet-driven methane storage and release in the Arctic
}

Alexey Portnov ${ }^{1}$, Sunil Vadakkepuliyambatta ${ }^{1}$, Jürgen Mienert ${ }^{1} \&$ Alun Hubbard ${ }^{1}$

It is established that late-twentieth and twenty-first century ocean warming has forced dissociation of gas hydrates with concomitant seabed methane release. However, recent dating of methane expulsion sites suggests that gas release has been ongoing over many millennia. Here we synthesize observations of $\sim 1,900$ fluid escape features-pockmarks and active gas flares-across a previously glaciated Arctic margin with ice-sheet thermomechanical and gas hydrate stability zone modelling. Our results indicate that even under conservative estimates of ice thickness with temperate subglacial conditions, a 500-m thick gas hydrate stability zone-which could serve as a methane sink-existed beneath the ice sheet. Moreover, we reveal that in water depths 150-520 m methane release also persisted through a 20-km-wide window between the subsea and subglacial gas hydrate stability zone. This window expanded in response to post-glacial climate warming and deglaciation thereby opening the Arctic shelf for methane release. 
$\mathrm{N}$ atural gas can exist in solid form of crystalline ice-like structures known as gas hydrates that are stable within the subsurface under high-pressure and low-temperature conditions bounded by the gas hydrate stability zone (GHSZ). The kinetics of hydrate formation and dissociation also critically depends on the supply and composition of gas and liquid water within available pore space of sediments, hence even under an appropriate envelope of GHSZ pressure and temperature conditions, gas hydrates are not, per se, guaranteed ${ }^{1}$. However, wherever persistent subsurface methane (or heavier fractions of natural gas) and water coexist within available pore space, then the GHSZ is a robust indication of the conditions under which gas hydrate is likely to form. The present distribution and stability of gas hydrates beneath oceans and permafrost, along with their potential to release large fluxes of methane and other potent greenhouse gases, are fundamental to determining long-term atmospheric composition and its impact on climate change. Previous research reveals that subglacial soils, lakes, peatlands and marine sediments can store significant reserves of carbon within a GHSZ beneath the palaeo-ice sheets that covered North America and also beneath the Antarctic ice sheet today ${ }^{2,3}$. It has been argued that as a result of active methanogenesis, this significant carbon pool could provide a major contribution to global atmospheric methane emissions and composition following deglaciation of Antarctica ${ }^{4}$. However, to date, few studies have investigated how gas hydrates responded to past climate change-specifically-the impact of extensive ice-sheet expansion on gas hydrate stability and dissociation during the last glaciation. In particular, three leading research questions warrant attention: how did the subglacial footprint of the former ice-sheet affect the GHSZ? How could this GHSZ govern methane storage and release across the glaciated margin? How could post-glacial ice-sheet retreat impact on this former subglacial gas hydrate reservoir?
Persistent and extensive discharge of methane gas flares into the water column offshore of Prins Karls Forland (PKF), western Svalbard has been reported since they were first observed in 2008 (refs 5,6). More than 1,000 individual gas flares, predominantly ejecting methane $\left(C_{1} \sim 98.9-99.9 \%\right)$ from known hydrocarbon sources ${ }^{7}$ cluster across a broad zone of the seabed between 80 and $420 \mathrm{~m} \mathrm{depth}^{8}$ (Fig. 1). Gas flares can be grouped in two distinct sets based on depth: a deep zone that spans $380-420 \mathrm{~m}$ below sea level (m.b.s.l.) and a shallow zone between 80 and 130 m.b.s.l. Deeper gas flares can theoretically be associated with the base of the present-day GHSZ, which pinches out on the seabed at $396 \mathrm{~m}$ water depth 6 . It has been argued that a temperature increase of $1{ }^{\circ} \mathrm{C}$ within the West Spitsbergen Current bottom water and/or annual fluctuations of $0.6-4.9^{\circ} \mathrm{C}$ has been sufficient to force a downslope migration of the GHSZ in this area from 360 to 396 m.b.s.l. over the past three decades ${ }^{5,6}$. Despite a lack of records of vertical fluid flow in the study area, U/Th isotope analyses on authigenic carbonate records reveal that there has been significant methane flow-induced precipitation at the deeper gas flares sites since at least $3 \mathrm{ka}$ (ref. 5). In contrast, shallow gas flares cluster across the main ridge of the Forlandet moraine complex ${ }^{9}$ (Fig. 1). The region is characterized by a sediment blanket that diminishes from several hundred metres over the continental slope to a minimum of a few tens of metres on the shelf ${ }^{10,11}$. The tectonically induced Forlandsundet graben (Fig. 1) is infilled with several kilometres thick sediment section ${ }^{2,13}$, and hence has major potential to host free gas. Sediment thickness to the southeast at Isfjorden varies up to $\sim 100 \mathrm{~m}$ (ref. 14). Hydrocarbon source rocks are extensive in the Svalbard region, including Triassic and Early Jurassic formations ${ }^{7}$, as well as organic-rich Miocene deposits ${ }^{15}$. The major hydrocarbon reservoirs within our study area are concentrated within Early and Middle Triassic source sequences ${ }^{7}$. Natural gas including thermogenic methane-the lightest hydrocarbon fraction-is generated under high pressure and



Figure 1 | The West Svalbard shelf at present. The western Svalbard margin (IBCAO v.3 (ref. 51) in grey and high-resolution multibeam data in the blue scale-see Methods) showing the observational compilation used in the modelling experiments along the transect a to $b$ (semi-transparent vertical curtain). Yellow and red triangles show geothermal temperature gradients $\left(19-112^{\circ} \mathrm{C} \mathrm{km}-1\right)^{5,35,36}$ and average long-term bottom water temperatures $\left(-0.8 \text { to } 2.2^{\circ} \mathrm{C}\right)^{32}$, respectively, which were used to constrain the LGM boundary conditions along the transect. Also indicated are the LGM marine limits ${ }^{25,28}$, used to estimate isostatic loading ( 25 and $48 \mathrm{~m}$ in white rounds), minimum ice-surface elevation ${ }^{21}$ (green flags), location of modern GHSZ, approximate LGM ice-sheet limit and modern gas flare locations (see Methods). Inset is the location of the study area in respect to pockmark fields (red ovals) and major tectonic lineaments of Hornsund fracture zone (dashed brown lines) across the western Svalbard margin. 
temperatures up to $200^{\circ} \mathrm{C}$ at depth within sedimentary basins from a mixture of insoluble organic compounds known as kerogen $^{16}$. In 1992, during exploratory drilling in Svalbard, gas blow outs from depths of $630 \mathrm{~m}$ beneath today's sediment surface brought operations to a complete halt ${ }^{17}$.

It is well established that the ultimate stable ice-sheet stand across the West Spitsbergen shelf was concurrent with maximum thickness and horizontal extent (representing the Last Glacial Maximum (LGM) stage) and persisted for at least $5 \mathrm{kyr}$ $(20-15 \mathrm{ka})^{18,19}$. Onshore and offshore radiocarbon dating ${ }^{20}$, cosmogenic ${ }^{10} \mathrm{Be}$ surface exposure dating ${ }^{20,21}$, numerical modelling ${ }^{22}$, offshore high-resolution multibeam ${ }^{23}$ and seismic surveys 9 reveal a LGM sequence that extended across the continental margin to the shelf break. By inference, the ice sheet in this sector was cold based and covered the Spitsbergen continental shelf to a distance of $\sim 45 \mathrm{~km}$ offshore ( $\sim 150 \mathrm{~m}$.b.s.l.; Fig. 1). Field evidence further reveals that the ice surface was at least $\geq 473 \mathrm{~m}$ above the present sea level (m.a.s.l.) as determined from the ${ }^{10} \mathrm{Be}$ exposure age of the boulders over the PKF, and $\sim 700-900$ m.a.s.l. over the west Spitsbergen $\operatorname{margin}^{21,22}$ (Fig. 1). Wet-based, fast-flowing ice streams discharged across the shelf from Kongsfjorden and Isfjorden, and bounded the cold-based ice lobe that flowed across our study area and west of $\mathrm{PKF}^{24}$.

Radiocarbon $\left({ }^{14} \mathrm{C}\right)$ dating of whale bones and mollusk shells sampled on the raised beaches define the earliest post-LGM marine limits on the northern PKF ( 25 m.a.s.l.) and western Spitsbergen (45-48 m.a.s.l.) ${ }^{25,26}$ (Fig. 1). The resulting sea level curves define a local glacio-isostatic loading scenario that was at least $100 \mathrm{~m}$ at PKF and western Spitsbergen. The time scale for ice-sheet stabilization at its LGM stand and subsequent retreat was $20-15 \mathrm{ka}$ in this region of western Svalbard, followed by complete deglaciation of the continental margin that was complete by $12-10 \mathrm{ka}$ (ref. 24). This glacial chronology is consistent with an initial phase of relatively slow post-glacial isostatic rebound of $1.5-5 \mathrm{~m} \mathrm{ka}^{-1}$ for West and North Svalbard that commenced at $\sim 13-12 \mathrm{ka}$, followed by an episode of accelerated uplift (15-30 $\mathrm{m} \mathrm{ka}^{-1}$ ) between 10.5 and $9 \mathrm{ka}$ (ref. 27).
In this study, we model the impact of the paleo-ice sheet on the GHSZ offshore of western Svalbard by integrating geophysical mapping with the glacial geology. Our results reveal a potentially large subglacial gas hydrate reservoir that accumulated under high-pressure/low-temperature LGM conditions and that would have subsequently dissociated, releasing methane during deglaciation and marine incursion.

\section{Results}

Modelling predicts thick GHSZ for $\mathbf{2 0} \mathbf{k a}$. The GHSZ model applied here uses a reconstructed LGM ice-sheet configuration, constrained by the available empirical evidence as described above $e^{9,23,28}$. Field data provide minimum constraints on ice-sheet thickness, isostatic loading and offshore extent to provide boundary conditions for two-dimensional, steady-state ice-sheet modelling under a perfect-plastic ice-flow assumption ${ }^{29,30}$ (Figs 1 and 2; see Methods). This LGM, cold-based ice-sheet reconstruction attained $\sim 700$-m thickness over Spitsbergen and thinned westward where it terminated into the ocean. We set the sea level datum to conform to the global eustatic sea level curve ${ }^{31}$, with zero-elevation aligned to its $20 \mathrm{ka}$ level $(120 \mathrm{~m}$ below the present; Fig. 2). Observations indicate significant subsidence of subglacial ground surface, accruing eastward and attaining $\sim 128 \mathrm{~m}$ under the West Spitsbergen margin (see Methods). LGM bottom water temperatures range from +2.3 to $+3.8^{\circ} \mathrm{C}$ from West to East along the transect (Fig. 2; Supplementary Fig. 1). These temperatures are $\sim 1{ }^{\circ} \mathrm{C}$ higher than the presentday average bottom water temperatures ${ }^{32}$ due to episodes of intensive Atlantic Water inflow and cold freshwater discharge from glaciated margins ${ }^{33,34}$. The juncture of the ocean-ice sheet interface critically controls the ground surface temperature change between the submarine and subglacial environments. It abruptly decreases from $+3.5^{\circ} \mathrm{C}$ within the ocean to $-4.5^{\circ} \mathrm{C}$ within the subglacial environment and consequently impacts significantly on the temperature distribution in the lower subsurface (Fig. 2; Supplementary Fig. 1).

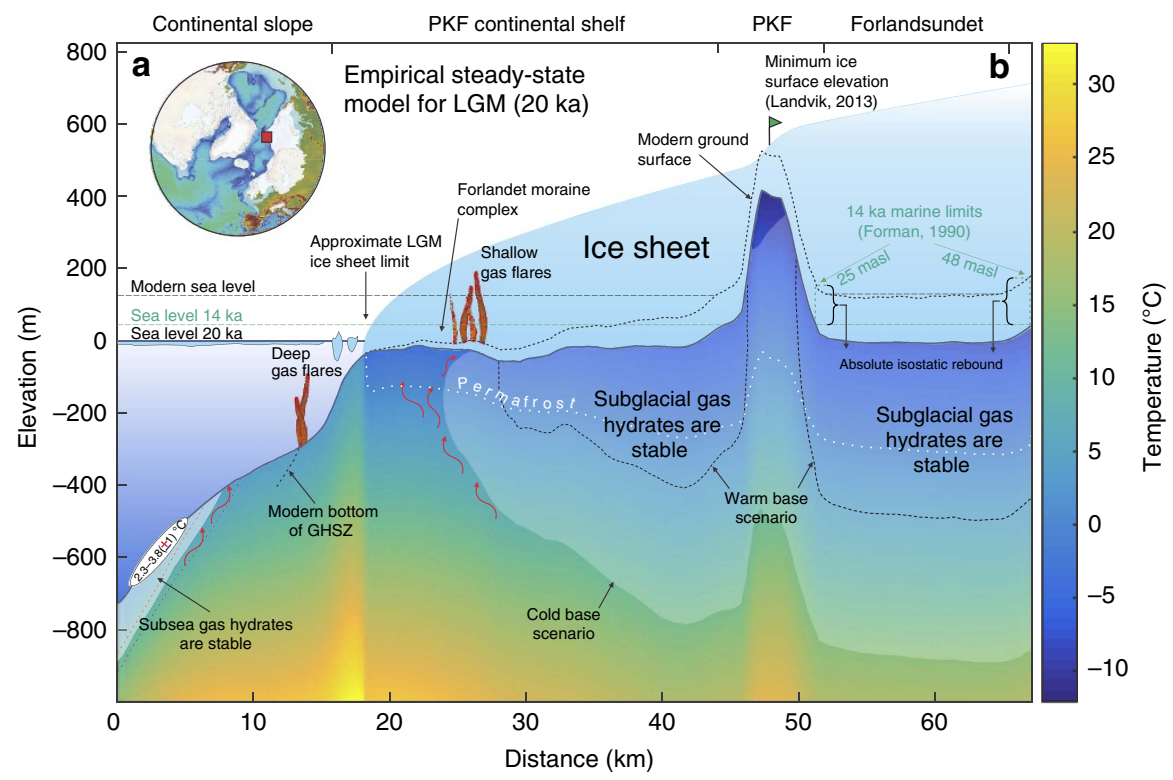

Figure 2 | Empirical steady-state model for the Last Glacial Maximum. Modelled for LGM (20 ka) ice-sheet and gas hydrate reconstruction showing both subsea and subglacial GHSZ in a minimum cold-based and warm-based ice-sheet scenario. The elevation datum is set at the LGM sea level ( $-120 \mathrm{~m}$ compared with present). Black dashed line shows the base of GHSZ in a warm-based ice-sheet scenario (pressure melting point temperature along the icesheet bed surface). Red and blue dashed lines show the shift of subsea GHSZ under $\pm 1^{\circ} \mathrm{C}$ bottom water temperature deviation. Gas-hydrate-free window existed between subsea and subglacial GHSZ during the LGM within the upper margin, leaving the potential for methane release (red arrows). Present-day seabed gas flares are confined to modern and ancient subsea and subglacial GHSZ pinch-out areas. 
These LGM conditions, combined with present-day heat-flow measurements $5,35,36$, were coupled with a thermal diffusion model to yield the two-dimensional distribution of subsurface temperature during the LGM. This is subsequently used to model an extensive subsea and subglacial GHSZ with a thickness in excess of $800 \mathrm{~m}$ below Forlandsundet that declines westward to where it abruptly tapers-out under the Forlandet moraine complex (Fig. 2). In this configuration, the subglacial GHSZ system resembles its deep offshore analogue, but with the ice sheet providing the high-pressure- and low-temperature loading conditions. Approximately, $20 \mathrm{~km}$ westward from where the subglacial GHSZ terminates, the subsea GHSZ pinches out across the seabed at $\sim 400 \mathrm{~m}$ water depth $(\sim 520 \mathrm{~m}$ below the present sea level; Fig. 2). Here and in contrast to the subglacial situation, the subsea GHSZ attained a maximum thickness of $\sim 160 \mathrm{~m}$ beneath the western and deepest submerged part of the transect (Fig. 2).

Modelling also reveals an upper margin window for potential methane release since the subsea and subglacial GHSZ configurations leave the ice-sheet margin with a GHSZ-free region. Hence, continuous gas release was possible, indeed, likely across the upper continental slope during the LGM, and, potentially, throughout the last glacial cycle. A cold-based ice-sheet scenario that also agrees with available field data predicts at least $100 \mathrm{~m}$ of thick subglacial permafrost above a $0^{\circ} \mathrm{C}$ isotherm, abruptly terminating under the shelf break due to the thermal diffusion beneath the subglacial/subsea interface (Fig. 2).

GHSZ is sensitive to environmental changes. The GHSZ modelling presented here is bounded by the subglacial and subsea temperature distributions associated with an optimal LGM ice-sheet reconstruction constrained by the glacial geological record and cosmogenic dating. We investigate the sensitivity of the modelled GHSZ to alteration of these boundary conditions by, first, changing the subglacial thermal conditions from a cold to a warm-based scenario and, second, by increasing the ice-sheet reconstruction from a minimum thickness in accordance to available field data, to a maximum profile.

The transition from a cold to temperate subglacial conditions (defined as being at pressure melting point) leads to a twofold decrease in GHSZ thickness (Fig. 2; Supplementary Fig. 1). Moreover, its surface exposure point shifts eastward $\sim 3 \mathrm{~km}$ across the modern Forlandet moraine complex. Model sensitivity to oceanic thermal conditions was investigated through a $\pm 1{ }^{\circ} \mathrm{C}$ deviation of the bottom water temperature profile and reveals a reciprocal $\sim \pm 1.5 \mathrm{~km}$ shift of the subsea GHSZ surface exposure point along the continental slope, fixing it between 390 and $450 \mathrm{~m}$ below LGM sea level (Fig. 2). The subsurface geothermal heat-flow pattern is interpolated from a sparse array of borehole measurements from across the region (see Methods) and also represents a source of uncertainty. The sensitivity experiments do though confirm that the approach we adopt along with our results are robust and indicate that even an increase in lithospheric temperature gradients by $10^{\circ} \mathrm{Ckm}^{-1}$ shifts the base of GHSZ upwards by some $100 \mathrm{~m}$ at most and hence, does not substantively detract from our findings.

The ice-sheet surface profile that optimally concurs with the available field evidence is achieved with a yield strength for perfect-plastic ice-sheet flow of $40 \mathrm{kPa}$ (ref. 29). An ice-sheet reconstruction with such a low-yield strength is glaciologically valid $^{30}$ and within bounds of published values under temperate subglacial conditions provides conservative, end-member, boundary conditions for pressure and thermal loading of the subglacial GHSZ during the LGM (that is, it yields the thinnest ice-sheet profile with warmest basal temperatures). Yield stress, if increased to a more typical value of $80 \mathrm{kPa}$ for a cold-based ice sheet $^{29,30}$ yields an increase both in ice thickness to a maximum of $950 \mathrm{~m}$ and associated subglacial GHSZ to $\sim 900 \mathrm{~m}$ beneath Forlandsundet (Supplementary Fig. 1). Under this maximum ice thickness reconstruction, the surface exposure point of subglacial GHSZ shifts $\sim 2.5 \mathrm{~km}$ westward, reflecting the steeper ice profile to the margin.

\section{Discussion}

Post-LGM eustatic sea level rise shifted the subsea GHSZ $\sim 6.5 \mathrm{~km}$ laterally up the continental slope, where it attained its present location at $396 \mathrm{~m}$.b.s.l. and is, today, marked by abundant gas flares that align parallel to the slope (Figs 1 and 2). We hypothesize that the lateral displacement of subsea GHSZ developed in parallel with the migration of gas-saturated fluids along the base of GHSZ (Fig. 2). This would impact on the formation of multiple fluid flow features within the glacio-marine sedimentary sequence as observed below the modern subsea GHSZ in recent high-resolution seismic data ${ }^{11,37}$.

We collate over 1,000 pockmarks and active gas flares across the shallow West Spitsbergen shelf and fjord environments (Fig. 3) ${ }^{14,23,38}$. Gas from deeper hydrocarbon sources is likely to migrate along the tectonic lineaments. Alternatively, release from thawing relic permafrost also should be considered ${ }^{8}$. However, 546 of 1,304 individual pockmarks studied in Isfjorden are confined to thrust faults, indicating focused fluid flow migration $^{38}$. The present-day gas discharge across the shelf west of PKF is coincident with the exposure point of subglacial GHSZ modelled here (Figs 1 and 2). This apparent match between our modelled GHSZ using a range of LGM ice-sheet scenarios and the incidence of observed gas flares is a robust yet paradoxical coincidence, since the subglacial GHSZ might have been expected to follow the post-LGM pattern of deglaciation. However, at present, there is no convincing observational evidence for pockmark and related gas flare activity that synchronously shifted eastward with on-going ice retreat and deglaciation. During its LGM stand, the West Spitsbergen ice sheet provided continuous high-pressure and thermal subglacial conditions for a period of at least $5 \mathrm{kyr}$ (ref. 18) -sufficient time for the establishment of an extensive and persistent GHSZ that hence had the potential for the formation of gas hydrates in regions with favourable geological setting ${ }^{39}$. On deglaciation, the former subglacial environment associated with the ice sheet was subject to marine incursion and became exposed to shallow marine environments, accompanied by decreased hydrostatic pressure and increased bottom temperatures related to the inflow of $\sim 2-3{ }^{\circ} \mathrm{C}$ warm Arctic water. This major environmental change was on-going and took place within $7 \mathrm{kyr}$ (refs 19,24) and resulted in a transient reduction of the previous thick subglacial GHSZ and associated permafrost layer. As a result, this sequence will have enabled triggering of seabed release of methane formerly trapped beneath the ice sheet in the form of gas hydrate, fuelled by deep hydrocarbon reservoirs that continued to drive methane upward through to the present day ${ }^{40,41}$. Active fluid flow and pockmark footprints across the vast area of western Spitsbergen margin have been mapped outside and inside the fjords (Fig. 3), coincident with known deeper petroleum reservoirs ${ }^{7}$. Our postglacial scenario for natural greenhouse gas release is supported by age constrains for Isfjorden pockmarks, which have been dated as post-glacial, and agree with the age estimation for Grønfjorden (southernmost branch of Isfjorden) pockmarks of $\sim 11.3 \mathrm{ka}$ (ref. 14) (Fig. 3). Such a geological setting appears to be characteristic for extensive post-LGM seabed gas escape across the Arctic 


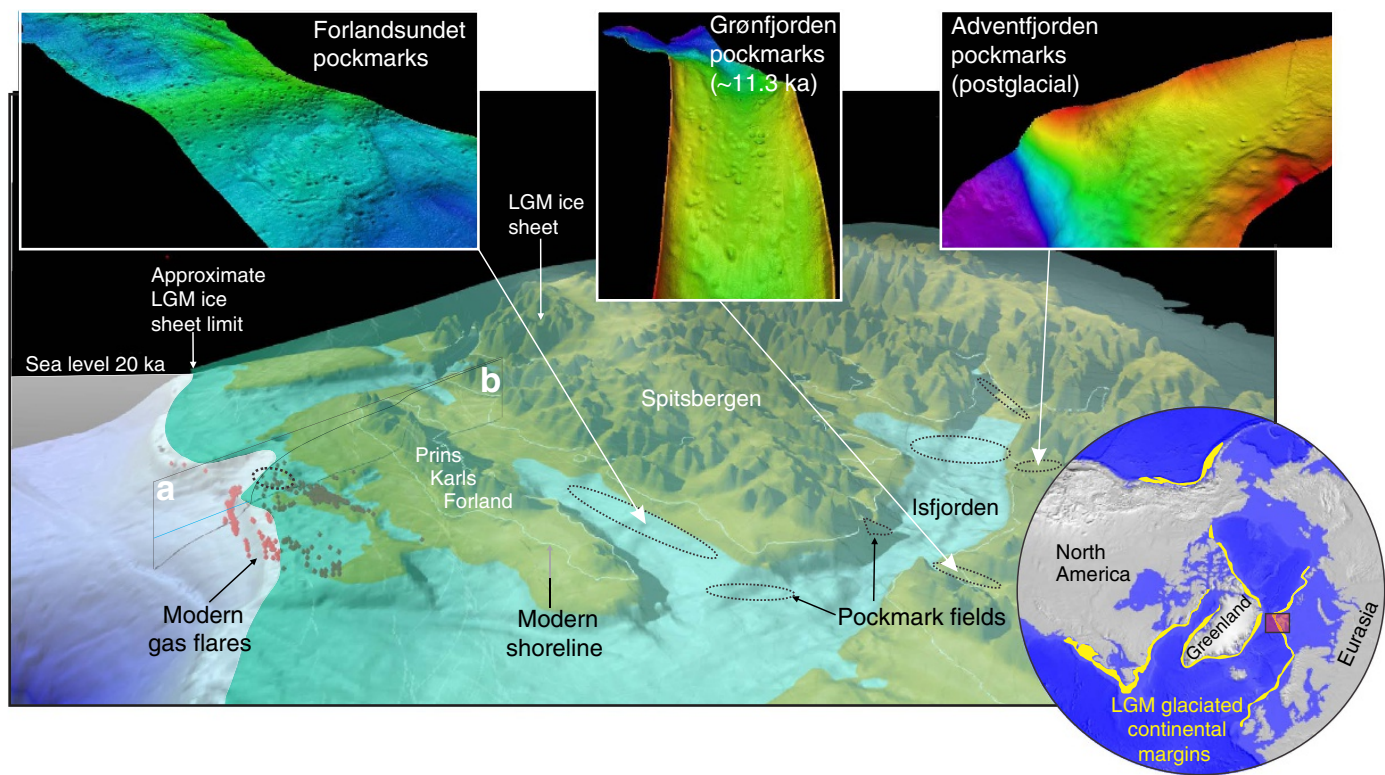

Figure 3 | Conceptual reconstruction of the glaciated western Svalbard margin. Dotted ellipses reveal the location of discovered pockmark fields that we infer to be due to the post-LGM retreat of the ice sheet. Upper insets demonstrate pockmark fields in high-resolution multibeam data. Lower inset schematically shows the widespread distribution of the formerly glaciated margins at the LGM across the Arctic, for which the western Svalbard margin is a potential GHSZ analogue.

margin and potentially across the US east coast continental margins where thousands of gas flares have been observed ${ }^{42}$.

High pressures to at least $50 \mathrm{MPa}$ coupled with temperatures $-5^{\circ} \mathrm{C}$ or cooler under the LGM ice sheet likely promoted expansion of the gas hydrate reservoir beneath the western Svalbard margin, but also left a $\sim 20$-km-wide gas-hydrate-free zone, which served as a corridor for upward migration of fluids and release of methane throughout the LGM. The North West Svalbard shelf and upper slope provides a robust test bed for understanding gas hydrate formation and dissociation across a formerly glaciated continental margin and reference point for further natural greenhouse gas release studies in Polar Regions. Former continental margins with a similar paleo-subglacial footprint and legacy extend some $20,000 \mathrm{~km}$ in the northern hemisphere where major ice sheets advanced across western Eurasia shallow shelves, Greenland and eastern and western American shelves (Fig. 3, inset). We infer that the ongoing deglaciation of these continental margins between 18 and $12 \mathrm{ka}$ (ref. 43), many of which are underlain by deep hydrocarbon reservoirs, would have likely been accompanied by widespread dissociation of gas hydrates and associated increase of methane flux from the seabed. In the outer continental shelves where the eustatic signal outpaced isostatic rebound, methane emissions from recently inundated shallow shelves (first tens of metres) would have been expelled into the atmosphere, similar to presentday process of methane transport across the shallow East Siberian Arctic Shelf ${ }^{44}$. This study not only implies the potential for significant gas hydrate storage and release capacity during past glacial/inter-glacial conditions but is also significant in its implication for current and future greenhouse gas release under the ongoing thinning and retreat of contemporary ice sheets and glaciers ${ }^{45}$.

\section{Methods}

Ice-sheet configuration and bed surface temperature modelling. The equilibrium profile of the West Svalbard ice sheet was obtained using a steady-state model based on the refined perfect-plastic assumption for ice flow ${ }^{29,30,46}$. Under these conditions, plastic-flow yielding a steady-state ice-sheet thickness distribution
$(\mathrm{H})$ occurs when basal shear stress $\left(\tau_{\mathrm{b}}\right)$ is equal to the yield stress $\left(\tau_{0}\right)$ at all points across the bed:

$$
\tau_{\mathrm{b}}=-\rho g \mathrm{H}\left(\frac{\partial \mathrm{h}}{\partial \mathrm{x}}\right)=\tau_{0}
$$

where $\rho$ is the density of ice, $g$ is the gravitation constant and $\mathrm{dh} / \mathrm{dx}$ is the ice-surface slope. This equation can be rearranged and applied to reconstruct former ice sheets using observational constraints that indicate its maximum extent, such as offshore moraines sequences, and its former surface from, for example, cosmogenically dated erratics and trimlines. To reconstruct the ice-sheet surface, the above equation is integrated numerically ${ }^{20}$, from the margin $(\mathrm{H}=0)$ under a given subglacial topographic profile with an appropriate value of yield strength (in our case 40 and $80 \mathrm{kPa}$ ), which for grounded ice masses can fall between 40 and $100 \mathrm{kPa}$ (refs 30,47).

Reconstruction of the LGM isostatic loading involved adjustment of past marine limits to account for relative sea level rise. Oldest post-LGM marine limits discovered on the PKF (25 m.a.s.l.) and Spitsbergen margin ( 48 m.a.s.l.) were dated as $14 \mathrm{ka}$ (refs 25,28 ; Fig. 2). Thus, given the $\sim 80 \mathrm{~m}$ sea level rise since $14 \mathrm{ka}$, we estimate the absolute isostatic rebound as $\sim 105$ and $\sim 128 \mathrm{~m}$ for PKF and Spitsbergen margin, respectively (Fig. 2).

We determine the steady-state cold-subglacial temperature distribution based on conservation of energy at the bed from vertical diffusion, advection and frictional heating as implemented and validated for various glaciers and the Antarctic ice sheet ${ }^{30,48,49}$. As implemented at Taylor Glacier, Dry valleys ${ }^{50}$, for its application to the LGM ice sheet in western Svalbard (Supplementary Fig. 1), we use a lapse rate of $-0.007^{\circ} \mathrm{Cm}^{-1}$, an accumulation rate of $0.3 \mathrm{~m} \mathrm{a}^{-1}$ and mean annual temperature at the margin of $-14^{\circ} \mathrm{C}$. For the warm-bed situation, basal temperatures are assumed to be at pressure meting point calculated according to $\mathrm{H} \times 8.70 \times 10^{-4}$ (ref. 30).

Subsurface heat-flow model. We sampled the seafloor depths along the transect (Fig. 1) at every $100 \mathrm{~m}$ from IBCAO v.3 gridded bathymetric data ${ }^{51}$ and adjusted the depths to sea level at $20 \mathrm{ka}$ (ref. 31). Then, a $671 \times 1,000$ cell temperature grid $(100 \times 1-\mathrm{m}$ cell dimensions) was generated, with its upper boundary at the seafloor and basal boundary $1 \mathrm{~km}$ below seafloor. To define initial temperature conditions, existing heat-flow measurements ${ }^{5,35,36}$ (Fig. 1) located near the selected transect were utilized. A spin-up model temperature grid was generated by assuming a one-dimensional linear temperature gradient, with ocean bottom water temperatures $^{32}$ adjusted to $20 \mathrm{ka}$ (refs 33,34 ) and ice-bottom temperatures (where ice exists) as the top boundary condition (Supplementary Fig. 1). To constrain the thermal diffusivity, we assumed a constant thermal conductivity of $2 \mathrm{~W} \mathrm{~m}^{-1} \mathrm{~K}^{-1}$ average density of $1,900 \mathrm{~kg} \mathrm{~m}^{-3}$ for the bulk sediments and an average specific heat capacity of $2,000 \mathrm{~J} \mathrm{~kg}^{-1} \mathrm{~K}^{-15}$

Assuming no significant in situ generation of heat, we run the two-dimensional finite difference heat-flow mode ${ }^{52}$ for $5 \mathrm{kyr}$ (assuming no significant variation of 
ice extent, sea level and ocean bottom temperatures in the study area during this period). The model is run for two different ice-bottom temperatures (Supplementary Fig. 1) and two different ice-sheet thicknesses, corresponding to 40 and $80 \mathrm{kPa}$ yield stress.

Gas hydrate stability modelling. To identify the base of methane hydrate stability, we integrate results from our heat-flow model with theoretical hydrate stability phase diagrams generated using the CSMHYD program ${ }^{1}$, which uses an algorithm based on Gibbs energy minimization and account for different pressure and temperature conditions, the composition of gas forming hydrates and the presence of inhibitors of hydrate formation (for example, salt). Assuming pure methane gas and a constant pore water salinity of $35 \%$, CSMHYD program estimates the pressure at which hydrates are stable for any given temperature. With temperature constrained from our heat-flow model, we estimated the hydrostatic pressure at each cell location using standard values for density of seawater $\left(1,027 \mathrm{~kg} \mathrm{~m}^{-3}\right)$ and acceleration due to gravity $\left(9.8 \mathrm{~m} \mathrm{~s}^{-2}\right)$. This pressure grid is then compared with theoretical predictions from CSMHYD program to determine the hydrate stability at each cell location.

Hydroacoustic data. High-resolution bathymetry data have been acquired in 20042014 onboard RV ‘Helmer Hanssen' by the Arctic University of Norway (UiT) using Kongsberg-Simrad EM300 multibeam echosounder system. Multibeam data were gridded with the cell $7-10 \mathrm{~m}$ in the water depths $\leq 200$ and $15-20 \mathrm{~m}$ in the water depths $>200 \mathrm{~m}$, which provided sufficient resolution for pockmark detections. Locations of gas flares offshore PKF were derived from previously published study ${ }^{8}$. New water column data, acquired in 2014 with Simrad ER-60 echosounder during UiT cruise onboard RV 'Helmer Hanssen' has been processed using Fledermaus software and included in the current study.

\section{References}

1. Sloan, E. D. \& Koh, C. A. Clathrate Hydrates of Natural Gases 3rd edn (CRC Press, 2008).

2. Weitemeyer, K. A. \& Buffett, B. A. Accumulation and release of methane from clathrates below the Laurentide and Cordilleran ice sheets. Global Planet. Change 53, 176-187 (2006).

3. Wadham, J. L. et al. Potential methane reservoirs beneath Antarctica. Nature 488, 633-637 (2012).

4. Wadham, J. L., Tranter, M., Tulaczyk, S. \& Sharp, M. Subglacial methanogenesis: A potential climatic amplifier? Global Biogeochem. Cycles 22, 1-16 (2008).

5. Berndt, C. et al. Temporal Constraints on Hydrate-Controlled Methane Seepage off Svalbard. Science 343, 284-287 (2014).

6. Westbrook, G. K. et al. Escape of methane gas from the seabed along the West Spitsbergen continental margin. Geophys. Res. Lett. 36, L15608 (2009).

7. Mørk, A. \& Bjorøy, M. Mesozoic Source Rocks on Svalbard (Springer, 1984).

8. Sahling, H. et al. Gas emissions at the continental margin west of Svalbard: mapping, sampling, and quantification. Biogeosciences 11, 6029-6046 (2014).

9. Landvik, J. Y. et al. Rethinking Late Weichselian ice-sheet dynamics in coastal NW Svalbard. Boreas 34, 7-24 (2005).

10. Amundsen, I., Blinova, M., Hjelstuen, B., Mjelde, R. \& Haflidason, H. The Cenozoic western Svalbard margin: sediment geometry and sedimentary processes in an area of ultraslow oceanic spreading. Mar. Geophys. Res. 32, 441-453 (2011).

11. Rajan, A., Mienert, J. \& Bünz, S. Acoustic evidence for a gas migration and release system in Arctic glaciated continental margins offshore NW-Svalbard. Mar. Pet. Geol. 32, 36-49 (2012).

12. Blinova, M., Thorsen, R., Mjelde, R. \& Faleide, J. I. Structure and evolution of the Bellsund Graben between Forlandsundet and Bellsund (Spitsbergen) based on marine seismic data. Norw. J. Geol. 89, 215-228 (2009).

13. Gabrielsen, R. H. et al. A Structural outline of Forlandsundet Graben, Prins Karls Forland, Svalbard. Nor. Geol. Tidsskr. 72, 105-120 (1992).

14. Forwick, M., Baeten, N. J. \& Vorren, T. O. Pockmarks in Spitsbergen fjords. Nor. J. Geol. 89, 65-77 (2009).

15. Knies, J. \& Mann, U. Depositional environment and source rock potential of Miocene strata from the central Fram Strait: introduction of a new computing tool for simulating organic facies variations. Mar. Pet. Geol. 19, 811-828 (2002).

16. Tissot, B. P. \& Welte, D. H. Petroleum Formation and Occurrence 2 edn (Springer-Verlag, 1984).

17. Elvevold, S., Dallmann, W. \& Blomeier, D. Geology of Svalbard (Norwegian Polar Institute, 2007).

18. Jakobsson, M. et al. Arctic Ocean glacial history. Quat. Sci. Rev. 92, 40-67 (2014).

19. Patton, H. et al. Geophysical constraints on the dynamics and retreat of the Barents Sea Ice Sheet as a palaeo-benchmark for models of marine ice-sheet deglaciation. Rev. Geophys. doi: 10.1002/2015RG000495 (2015).
20. Landvik, J. Y. et al. Northwest Svalbard during the last glaciation: Ice-free areas existed. Geology 31, 905-908 (2003).

21. Landvik, J. Y. et al. 10Be exposure age constraints on the Late Weichselian ice-sheet geometry and dynamics in inter-ice-stream areas, western Svalbard. Boreas 42, 43-56 (2013).

22. Landvik, J. Y. et al. The Last Glacial Maximum of Svalbard and the Barents Sea Area: Ice Sheet Extent and Configuration. Quat. Sci. Rev. 17, 43-75 (1998).

23. Ottesen, D. A. G., Dowdeswell, J. A., Landvik, J. Y. \& Mienert, J. Dynamics of the Late Weichselian ice sheet on Svalbard inferred from high-resolution sea-floor morphology. Boreas 36, 286-306 (2007).

24. Ingólfsson, Ó. \& Landvik, J. Y. The Svalbard-Barents Sea ice-sheet - Historical, current and future perspectives. Quat. Sci. Rev. 64, 33-60 (2013).

25. Andersson, T., Forman, S. L., Ingolfsson, O. \& Manley, W. F. Late Quaternary environmental history of central Prins Karls Forland, western Svalbard. Boreas 28, 292-307 (1999)

26. Forman, S. L. Post-glacial relative sea-level history of northwestern Spitsbergen, Svalbard. Geol. Soc. Am. Bull. 102, 1580-1590 (1990).

27. Forman, S. L. et al. A review of postglacial emergence on Svalbard, Franz Josef Land and Novaya Zemlya, northern Eurasia. Quat. Sci. Rev. 23, 1391-1434 (2004).

28. Forman, S. L. Post-glacial relative sea-level history of northwestern Spitsbergen, Svalbard. Geol. Soc. Am. Bull. 102, 1580-1590 (1990).

29. Nye, J. F. The flow of glaciers and ice-sheets as a problem in plasticity. Proc. $R$. Soc. Lond. A 207, 554-572 (1951).

30. van der Veen, C. J. Fundamentals of Glacier Dynamics (Taylor \& Francis, 1999)

31. Fleming, K. et al. Refining the eustatic sea-level curve since the Last Glacial Maximum using far- and intermediate-field sites. Earth Planet. Sci. Lett. 163, 327-342 (1998).

32. Boyer, T. P. et al. in NOAA Atlas NESDIS 72 (ed. Center NOD) (National Oceanic And Atmospheric Administration, 2013).

33. Hebbeln, D., Dokken, T., Andersen, E. S., Hald, M. \& Elverhoi, A. Moisture supply for northern ice-sheet growth during the Last Glacial Maximum. Nature 370, 357-360 (1994).

34. Rasmussen, T. L., Thomsen, E. \& Nielsen, T. Water mass exchange between the Nordic seas and the Arctic Ocean on millennial timescale during MIS 4-MIS 2. Geochem. Geophys. Geosyst. 15, 530-544 (2014).

35. Crane, K., Sundvor, E., Buck, R. \& Martinez, F. Rifting in the northern Norwegian-Greenland Sea: Thermal tests of asymmetric spreading. J. Geophys. Res. Solid Earth 96, 14529-14550 (1991).

36. Isaksen, K., Holmlund, P., Sollid, J. L. \& Harris, C. Three deep Alpinepermafrost boreholes in Svalbard and Scandinavia. Permafrost Periglacial Processes 12, 13-25 (2001).

37. Sarkar, S. et al. Seismic evidence for shallow gas-escape features associated with a retreating gas hydrate zone offshore west Svalbard. J. Geophys. Res. Solid Earth 117, B09102 (2012).

38. Roy, S., Hovland, M., Noormets, R. \& Olaussen, S. Seepage in Isfjorden and its tributary fjords, West Spitsbergen. Mar. Geol. 363, 146-159 (2015).

39. Sloan, E. D. \& Koh, C. A. Clathrate Hydrates of Natural Gases 3rd edn (CRC Press, 2007).

40. Damm, E., Mackensen, A., Budéus, G., Faber, E. \& Hanfland, C. Pathways of methane in seawater: Plume spreading in an Arctic shelf environment (SW-Spitsbergen). Cont. Shelf Res. 25, 1453-1472 (2005).

41. Knies, J., Damm, E., Gutt, J., Mann, U. \& Pinturier, L. Near-surface hydrocarbon anomalies in shelf sediments off Spitsbergen: evidences for past seepages. Geochem. Geophys. Geosyst. 5, CiteID Q06003 (2004).

42. Skarke, A., Ruppel, C., Kodis, M., Brothers, D. \& Lobecker, E. Widespread methane leakage from the sea floor on the northern US Atlantic margin. Nat. Geosci. 7, 657-661 (2014).

43. Bennett, M. in Boreas. (eds Benn, D. I. \& Evans, D. J.) 40, 555-555 (Blackwell Publishing Ltd (2011).

44. Shakhova, $\mathrm{N}$ et al. Ebullition and storm-induced methane release from the East Siberian Arctic Shelf. Nat. Geosci. 7, 64-70 (2014).

45. Hanna, E et al. Ice-sheet mass balance and climate change. Nature 498, 51-59 (2013).

46. Reeh, N. A plasticity theory approach to the steady-state shape of a threedimensional ice sheet. J. Glaciol. 28, 431-455 (1982).

47. Paterson, W. S. B. The Physics of Glaciers (Pergamon Press, Elsevier Science Ltd, 1994).

48. Budd, W. F., Jenssen, D. \& Radok, U. Derived Physical Characteristics of the Antarctic Ice Sheet (University of Melbourne, 1971).

49. Robin, G. deQ. Ice movement and temperature distribution in glaciers and ice sheets. J. Glaciol. 3, 589-606 (1955).

50. Hubbard, A., Lawson, W., Anderson, B., Hubbard, B. \& Blatter, H. Evidence for subglacial ponding across Taylor Glacier, Dry Valleys, Antarctica. Ann. Glaciol. 39, 79-84 (2004).

51. Jakobsson, M. et al. The International Bathymetric Chart of the Arctic Ocean (IBCAO) Version 3.0. Geophys. Res. Lett. 39, L12609 (2012). 
52. Phrampus, B. J. \& Hornbach, M. J. Recent changes to the Gulf Stream causing widespread gas hydrate destabilization. Nature 490, 527-530 (2012).

\section{Acknowledgements}

The research is part of the Centre for Arctic Gas Hydrate, Environment and Climate and was supported by the Research Council of Norway through its Centres of Excellence funding scheme grant No. 223259. A.P. was supported by a Statoil fellowship grant through the UiT The Arctic University of Norway. We are thankful to Ellen Damm and two anonymous reviewers for very constructive comments, which helped to improve the manuscript.

\section{Author contributions}

J.M. and A.P. developed the ideas that led to the paper. A.P. processed and interpreted hydroacoustic data and designed the figures; S.V. applied heat-flow and GHSZ modelling. J.M., A.P. and S.V. wrote the original manuscript. A.H. modelled the ice-sheet thickness and temperature reconstruction and advised on the study's scope and conception. All authors contributed to the final editing of the manuscript.

\section{Additional information}

Supplementary Information accompanies this paper at http://www.nature.com/ naturecommunications

Competing financial interests: The authors declare no competing financial interests.

Reprints and permission information is available online at http://npg.nature.com/ reprintsandpermissions/

How to cite this article: Portnov, A. et al. Ice-sheet-driven methane storage and release in the Arctic. Nat. Commun. 7:10314 doi: 10.1038/ncomms10314 (2016).

\section{(c) (i)}

This work is licensed under a Creative Commons Attribution 4.0 International License. The images or other third party material in this article are included in the article's Creative Commons license, unless indicated otherwise in the credit line; if the material is not included under the Creative Commons license, users will need to obtain permission from the license holder to reproduce the material. To view a copy of this license, visit http://creativecommons.org/licenses/by/4.0/ 